\title{
Global burned-land estimation in Latin America using MODIS composite data
}

Article

Published Version

Chuvieco, E., Opazo, S., Sione, W., Del Valle, H., Anaya, J., Di Bella, C., Cruz, I., Manzo, L., López-Saldaña, G., Mari, N., González-Alonso, F., Morelli, F., Setzer, A., Csiszar, I., Kanpandegi, J. A., Bastarrika, A. and Libonati, R. (2008) Global burned-land estimation in Latin America using MODIS composite data. Ecological Applications, 18 (1). pp. 64-79. ISSN 0051-0761 doi: https://doi.org/10.1890/06-2148.1 Available at https://centaur.reading.ac.uk/39133/

It is advisable to refer to the publisher's version if you intend to cite from the work. See Guidance on citing.

Published version at: http://www.ncbi.nlm.nih.gov/pubmed/18372556

To link to this article DOI: http://dx.doi.org/10.1890/06-2148.1

Publisher: Ecological Society of America

Publisher statement: Copyright by the Ecological Society of America

All outputs in CentAUR are protected by Intellectual Property Rights law, including copyright law. Copyright and IPR is retained by the creators or other copyright holders. Terms and conditions for use of this material are defined in the End User Agreement. 


\section{CentAUR}

Central Archive at the University of Reading

Reading's research outputs online 


\title{
GLOBAL BURNED-LAND ESTIMATION IN LATIN AMERICA USING MODIS COMPOSITE DATA
}

\author{
Emilio Chuvieco, ${ }^{1,13}$ Sergio Opazo, ${ }^{2}$ Walter Sione, ${ }^{3}$ Héctor del Valle, ${ }^{4}$ Jesús Anaya, ${ }^{5}$ Carlos Di Bella, ${ }^{6}$ \\ Isabel Cruz, ${ }^{7}$ Lilia Manzo, ${ }^{8}$ Gerardo López, ${ }^{7}$ Nicolas Mari, ${ }^{6}$ Federico González-Alonso, ${ }^{9}$ Fabiano Morelli, ${ }^{10}$ \\ Alberto Setzer, ${ }^{10}$ Ivan Csiszar, ${ }^{11}$ Jon Ander Kanpandegi, ${ }^{6}$ Aitor Bastarrika, ${ }^{12}$ and Renata Libonati ${ }^{10}$ \\ ${ }^{1}$ Departamento de Geografía, Colegios 2, Universidad de Alcalá, Alcalá de Henares, Spain \\ ${ }^{2}$ Escuela de Ciencia y Tecnologias Agropecuarias, Universidad de Magallanes, Punta Arenas, Chile \\ ${ }^{3}$ UNLU (Universidad de Luján), Departamento de Ciencias Básicas, PRODITEL (Programa de Desarrollo e Investigación en \\ Teledetección) y UADER-CEREGeo (Centro Regional de Geomática, Universidad de Entre Rios), Luján, Argentina \\ ${ }^{4}$ Centro Nacional Patagónico (CENPAT), CONICET (Comisión Nacional de Ciencia y Tecnología), Puerto Madryn, Argentina \\ ${ }^{5}$ Facultad de Ingeniería Ambiental, Universidad de Medellín, Medellin, Colombia \\ ${ }^{6}$ Instituto de Clima y Agua, INTA (Instituto Nacional de Tecnología Agropecuaria-Castelar, Buenos Aires, Argentina \\ ${ }^{7}$ CONABIO (Comisión Nacional para el Conocimiento y Uso de la Biodiversidad), Mexico City, Mexico \\ ${ }^{8}$ Instituto de Geografía, Universidad Nacional Autónoma de México, Mexico City, Mexico \\ ${ }^{9}$ Centro de Investigación Forestal (CIFOR), Instituto Nacional de Investigación y Tecnología Agraria y Alimentaria (INIA), \\ Madrid, Spain \\ ${ }^{10}$ Centro de Previsão de Tempo e estudos Climáticos, Instituto Nacional de Pesquisas Espacias, Sao Jose dos Campos, Brazil \\ ${ }^{11}$ University of Maryland, Department of Geography, College Park, Maryland 20742 USA \\ ${ }^{12}$ Departamento de Ingeniería Topográfica, Universidad del País Vasco, Vitoria, Spain
}

\begin{abstract}
This paper presents results of the AQL2004 project, which has been developed within the GOFC-GOLD Latin American network of remote sensing and forest fires (RedLatif). The project intended to obtain monthly burned-land maps of the entire region, from Mexico to Patagonia, using MODIS (moderate-resolution imaging spectroradiometer) reflectance data. The project has been organized in three different phases: acquisition and preprocessing of satellite data; discrimination of burned pixels; and validation of results. In the first phase, input data consisting of 32-day composites of MODIS 500-m reflectance data generated by the Global Land Cover Facility (GLCF) of the University of Maryland (College Park, Maryland, USA) were collected and processed. The discrimination of burned areas was addressed in two steps: searching for "burned core" pixels using postfire spectral indices and multitemporal change detection and mapping of burned scars using contextual techniques. The validation phase was based on visual analysis of Landsat and CBERS (China-Brazil Earth Resources Satellite) images. Validation of the burned-land category showed an agreement ranging from $30 \%$ to $60 \%$, depending on the ecosystem and vegetation species present. The total burned area for the entire year was estimated to be $153215 \mathrm{~km}^{2}$. The most affected countries in relation to their territory were Cuba, Colombia, Bolivia, and Venezuela. Burned areas were found in most land covers; herbaceous vegetation (savannas and grasslands) presented the highest proportions of burned area, while perennial forest had the lowest proportions. The importance of croplands in the total burned area should be taken with reserve, since this cover presented the highest commission errors. The importance of generating systematic products of burned land areas for different ecological processes is emphasized.
\end{abstract}

Key words: biomass burning; burn area index; burn scars; burned area; forest fires; Latin America; MODIS; normalized burn ratio; remote sensing.

\section{INTRODUCTION}

Forest fires have an important role in global ecological and climate systems, being responsible for a significant part of greenhouse gas emissions to the atmosphere (van der Werf et al. 2004) and for land degradation and soil erosion processes (Levine 1996). Additionally, many studies have identified wildland fires

Manuscript received 31 December 2006; revised 24 April 2007; accepted 2 August 2007. Corresponding Editor: E. Cuevas.

${ }^{13}$ E-mail: emilio.chuvieco@uah.es as the most comprehensive tool for forest clearing in the tropical regions (Roberts 2000), and therefore the importance of studying global patterns of fire occurrence increases. According to Liousse et al. (2004), the amount of $\mathrm{CO}_{2}$ emissions derived from biomass burning in Latin America is eight times larger than its emissions derived from fossil fuel combustion (see Plate 1). Therefore, it is critical to improve current estimations of burned land areas in the region, from both an ecological and management point of view.

Statistics on wildland fire are generally available in developed countries, while in other areas the estimations 
are generally poor or not available. According to the latest Food and Agriculture Organization of the United Nations (FAO) statistics (FAO 2006) from 1998 to 2002 more than 3 million ha were burned in Latin America. These estimates are very low compared to other projects based on satellite data for the same region (Boschetti et al. 2004) and could be related to the lack of consistent assessment of burned areas in most countries.

The use of remotely sensed data is a sound alternative to traditional field methods for estimating burned-land areas. Satellite observation data of Earth provide timely, cost effective, and spatially comprehensive views of fireaffected areas and fire occurrence patterns (Di Bella et al. 2006). The use of these data for fire effects assessment has grown notably in the last decades, using both high and low resolution satellite sensors (Ahern et al. 2001). Global approaches to map burn areas were based on NOAA-AVHRR images during the 1990s, and multitemporal comparisons between spectral vegetation indices was a common technique used (Kasischke and French 1995, Martín and Chuvieco 1995, Barbosa et al. 1999, Pereira 1999), although some combinations of thermal infrared and shortwave channels were also used (Fraser et al. 2000).

More recently, other sensors with greater sensitivity to discriminate burn scars have been used to create a global inventory of burned areas. In 2000, two worldwide projects were developed: the GBA2000 (Tansey et al. 2004) and the GLOBSCAR (Simon et al. 2004). The former was based on SPOT-Vegetation data and it was coordinated by the Joint Research Center of the European Union. The latter was an initiative of the European Space Agency, and it was based on ERS-2 ATSR images. Finally, the MODIS program soon plans to release a standard product on burned land areas at the global scale, which will be based on a multitemporal change detection approach to analyze differences between modeled and actual reflectance, and to take into account bidirectional reflectance distribution function (BRDF) corrections (Roy et al. 2005b). Other authors have used active fire detections derived from thermal channels to obtain global estimates of burned areas (Giglio et al. 2006), but the accuracy of this approach strongly varies in different ecozones.

One of the bottlenecks of these global approaches is the assessment of results, which is very complex and costly. However, proper assessment of global products is becoming increasingly important in order to reduce uncertainties when using them as an input to other estimation models (Boschetti et al. 2004).

The critical need to assess global products has led to the creation of regional networks, which can take advantage of local expertise to fine tune global algorithms and make them more suitable for specific ecosystems. The Global Observation of Forest and Land Cover Dynamics (GOFC-GOLD) program is a coordinated international effort working to provide ongoing space-based and in situ observations of forests and other vegetation cover for the sustainable management of terrestrial resources and to obtain an accurate, reliable, quantitative understanding of the terrestrial carbon budget (information available online). ${ }^{14}$ Inside this program, the Fire Implementation Team has encouraged the creation of regional networks, which provide a mechanism for the sharing of resources and expertise. Within this framework, a Latin American GOFCGOLD network (named RedLatif) was created in 2002. RedLatif intended to foster the relationships between scientists working in remote sensing and fire applications throughout the region. One of the first objectives of this network was the creation of a burned land map of the region, which could be used to assess the spatial and temporal patterns of fire occurrence at the continental scale.

The importance of Latin America in the context of fire occurrence and global deforestation is evident. A recent report from the FAO (2006), which focused on the evolution of forested areas between 2000 and 2005, emphasized the importance of Latin America in global deforestation rates. In fact, this region has the highest rate of annual forest conversion, with almost 5 million ha per year, which accounts for $67 \%$ of the world's deforestation. A great amount of this deforestation is caused by wildland fires (Cochrane et al. 1999), and therefore it is critical to better understand fire occurrence patterns in the region. Additionally, Latin American biomass burning is a very important source of global gas emissions, around $16 \%$ according to recent studies (van der Werf et al. 2006).

The main goal of this paper is to present methods to generate a monthly map of burned areas in Latin America for 2004 and to analyze the spatial and temporal patterns of fire occurrence derived from this product. This project, developed within the RedLatif network, was named AQL2004 (Area Quemada en Latinoamerica, the Spanish translation of Burned Land Areas in Latin America for 2004). The project was intended to improve current estimations of burned areas in the region, thus providing input to global analysis of ecological impacts of fires, to better understand the relations between fire occurrence and biodiversity, and to improve the assessment of atmospheric emissions derived from wildland fires. The extension of the area should facilitate the creation of a global perspective of spatial and temporal patterns of fire occurrence that may be applicable to other regions. Considering the limitations of the input data available for the project, a burn patch size of 250 hectares was selected as the minimum mapping unit.

The AQL2004 project was proposed on a volunteer basis as part of the RedLatif network activity, and without specific funding. Therefore, input data for generation and validation of the product were restricted

$14\langle$ http://www.fao.org/gtos/gofc-gold/index.html $\rangle$ 
TABLE 1. MODIS (moderate-resolution imaging spectroradiometer) spectral bands of the 32-day reflectance composite.

\begin{tabular}{ccc}
\hline \hline Band number & Wavelength $(\mathrm{nm})$ & Spectral region \\
\hline 1 & $620-670$ & red \\
2 & $841-876$ & near infrared \\
3 & $459-479$ & blue \\
4 & $545-565$ & green \\
5 & $1230-1250$ & SWIR \\
6 & $1628-1652$ & SWIR \\
7 & $2105-2155$ & SWIR \\
\hline
\end{tabular}

Note: SWIR is short-wave infrared reflectance.

to satellite data that was publicly available. As we will comment later, this limitation has impacted the results of the project, but it has also provided a good cooperation scenario that might be useful for other active networks. External funds were limited to coordination activities (three meetings) and were obtained from the NASA-START program (information available online). ${ }^{15}$

\section{Methods}

\section{Image acquisition and preprocessing}

Moderate-resolution imaging spectroradiometer (MODIS) images were selected for the project, since they provided a good spatial, spectral and temporal resolution while being freely downloadable (available online). ${ }^{16}$ The MODIS program offers a wide range of standard products covering land, atmospheric, and water applications (information available online). ${ }^{17}$ The standard reflectance product MOD09 is an 8-day composite of atmospherically corrected and calibrated surface reflectances at $500 \times 500 \mathrm{~m}$ pixel size, covering the whole Earth in tiles of $1200 \times 1200 \mathrm{~km}$ using a Sinusoidal Projection system. Additionally, the MODIS program offers another reflectance product (MOD43) that includes a correction of the observation and illumination effects (BRDF). This product includes the same bands as the MOD09, but with lower spatial (1000 $\times 1000 \mathrm{~m}$ ) and temporal (16-day) resolution. Finally, the University of Maryland's Global Land Cover Facility (GLCF) compiled 32-day composites of the MOD09 product. This is not a standard product of the MODIS program, but it has been used for land cover analysis, and it is also freely available (Townshend et al. 2003). The product has the same spatial and spectral resolution as MOD09 and chooses for each pixel the second lowest albedo value among the four 8-day composites that formed a single 32-day product (available online). ${ }^{18}$ This criterion is used to reduce clouds and cloud shadows in the final composites. The product includes the seven reflectance bands of MODIS with $500 \times 500 \mathrm{~m}$ pixel size

\footnotetext{
$15\langle$ http://www.start.org/Program/GOFC.html $\rangle$

16 http://modis.gsfc.nasa.gov/about/

$17\langle$ http://modis.gsfc.nasa.gov/data/dataprod/index.php $\rangle$

$18\langle$ http://glcfapp.umiacs.umd.edu:8080/esdi/index/jsp $\rangle$
}

(Table 1). This product is joined together by continents as a mosaic and uses the Goode Interrupted Homolosine projection. After analyzing the advantages and disadvantages of the different products, the 32-day composites produced by GLCF were selected, since they provided an adequate temporal resolution for our project (monthly burn-area estimations) and reduced the effects of cloud and cloud shadow contamination of the 8-day composites. In addition, this product does not require the user to perform geometric transformations to obtain continental mosaics, while the standard MODIS products are offered in $1200 \times 1200 \mathrm{~km}$ tiles.

Twelve 32-day composites were downloaded from the GLCF site, covering the period from December 2003 through December 2004. The complete mosaic of North and South America was divided in 12 subregions, which were assigned to each of the participant groups. The aim of each group was to develop a basic discrimination algorithm for the study area that could be later compared with other areas for deriving a burned land algorithm that could be used for the entire region.

In spite of the temporal compositing of daily data, cloud contamination was still observed in the 32-day composites, especially in some tropical regions of the Amazon Basin and Central Venezuela. A cloud screening was performed with three reflectance bands using the following criteria: if (band $2>25$ AND band $3>60$ AND band $5 /$ band $3>0.7$ ) then label as cloud, where bands 2, 3, and 5 are MODIS reflectance in percentage.

To avoid confusion between burn scars and low reflectance over some non-vegetated areas, such as dark soils or water, a vegetation mask was derived from the Vegetation Continuous Fields (VCF) data set (Hansen et al. 2002). The product was produced by the GLCF at the University of Maryland from the same 32-day MODIS composite data used in our project and it was generated from spectral unmixing analysis (Hansen et al. 2005). The VCF product was downloaded from the GLCF web site and included three data files, with percentage of trees, bare soil, and herbaceous vegetation, covering the period between November 2000 and November 2001 (available online). ${ }^{19}$ The values are scaled between 1 and 100 and the sum of the three layers estimates $100 \%$ of ground cover.

For the AQL2004 project, the "non-burnable" category was defined as pixels that had $>80 \%$ of bare soil, or alternatively those that met two conditions: $<70 \%$ herbaceous and $<10 \%$ trees. Otherwise, they were considered areas that could be burned. Considering the great variety of ecosystems in Latin America, this criterion was not applied at the beginning of the process to avoid potential errors in areas of low vegetation coverage. It was used as a filter at the final stages, but regional thresholds were also applied in the semi-arid regions of Argentina and Chile.

$19\langle$ http://glcf.umiacs.umd.edu/data/vcf/ $\rangle$ 


\section{Burned-land discrimination methods}

Mapping of burn scars was based on a two-step approach. The first step was dedicated to selecting the most severely burned pixels in each burn scar. The second step was aimed at improving the mapping of each burned area by including the neighboring pixels of those previously identified. The goal of the first phase was to reduce, as much as possible, the commission errors (pixels labeled as burned areas that were not actually burned), while the objective of the second phase was to reduce the omission error (pixels that were indeed burned and were not classified as such; Chuvieco et al. 2002). This two-step burned-land mapping approach should produce better results than trying to classify all the burn scars in a single algorithm, since it was expected to find a great diversity of spectral signatures in such a large territory.

Discrimination of "core" burned pixels.-The first phase of our discrimination algorithm was based on applying multiple thresholds to the postfire images as well as on multitemporal change detection. From the original 32-day reflectance products, two vegetation indices were computed to improve the separability of burned and unburned areas. The normalized burn ratio (NBR) was proposed in the 1990s to discriminate burned areas (López García and Caselles 1991, Key and Benson 2006) based on the contrast between near-infrared (NIR) and short-wave infrared (SWIR) reflectance:

$$
\mathrm{NBR}=\frac{\rho_{\mathrm{SWIR}}-\rho_{\mathrm{NIR}}}{\rho_{\mathrm{NIR}}+\rho_{\mathrm{SWIR}}}
$$

where $\rho_{\text {SWIR }}$ and $\rho_{\text {NIR }}$ are NIR (generally from 700 to $900 \mathrm{~nm}$ ) and SWIR (from 2100 to $2300 \mathrm{~nm}$ ), respectively. The index has a range from -1 to 1 , with the largest number being the most severe burn. Recently, this index has been extensively used in the framework of the FIREMON (Fire Effects Monitoring and Inventory System) project (Key and Benson 2006) and will be the basis for mapping burn severity in the United States from Landsat-TM/ETM + data (available online). ${ }^{20} \mathrm{We}$ should clarify that, for this paper, the NBR has been formulated after changing the sign of the numerator $\left(\rho_{\text {SWIR }}-\rho_{\text {NIR }}\right.$ instead of $\left.\rho_{\text {NIR }}-\rho_{\text {SWIR }}\right)$ to keep the scale consistent with the index definition, since reflectance in the SWIR is higher than in the NIR for most recently burned areas. Since this index is intended to discriminate burn severity, only high values of the index should be of interest for the first phase of the project, leaving the intermediate values to be classified in the second phase.

In addition to the NBR, a burned area index (BAI) was also used in this project to confirm that the pixels selected in the first phase were as close as possible to charcoal signal, thus avoiding false alarms with other potential mixtures of dark reflectance objects. The BAI was developed initially for NOAA-AVHRR images (Martín 1998) and was recently adapted to MODIS data, also

${ }^{20}\langle$ http://burnseverity.cr.usgs.gov/fire_main.asp $\rangle$
TABLE 2. Thresholds to determine burned-land core pixels in the first phase of the mapping algorithm.

\begin{tabular}{lc}
\hline \multicolumn{1}{c}{ Variable } & Threshold value \\
\hline Postfire image & \\
BAI MODIS & $>99$ \\
NBR & $>0$ \\
Multitemporal change & $>1.74$ \\
BAI MODIS $_{t}-$ BAI MODIS & \\
NBR $_{t-1}-$ NBR $_{t-1}$ & $>0.35$ \\
\hline
\end{tabular}

Note: BAI is burned area index; NBR is the normalized burn ratio, which discriminates burned areas based on the contrast between near-infrared (NIR) and short-wave infrared (SWIR) reflectance.

using the NIR and SWIR bands (Martín et al. 2005). This index is defined as the inverse quadratic distance of every pixel to the convergence point of charcoal:

$$
\mathrm{BAI}=\frac{1}{\left(\mathrm{Pc}_{\mathrm{SWIR}}-\rho_{\mathrm{SWIR}}\right)^{2}+\left(\mathrm{Pc}_{\mathrm{NIR}}-\rho_{\mathrm{NIR}}\right)^{2}}
$$

where $\rho_{\text {SWIR }}$ and $\rho_{\text {NIR }}$ have the same meaning as in Eq. 1 , and $\mathrm{Pc}_{\mathrm{SWIR}}$ and $\mathrm{Pc}_{\mathrm{NIR}}$ are the convergence points in the same bands. After an analysis of sampled burned pixels in different types of fires, they were fixed as 0.2 and 0.08 , respectively.

The thresholds for discriminating burned pixels were based on NBR and BAI values of the postfire image, as well as the multitemporal comparisons of these indices with previous images. These images were computed by postfire $(t)$ minus prefire $(t-1)$ values. The prefire conditions were taken from the 32-day composite previous to the one that was being analyzed, starting in January 2004, which was the first target composite and was compared to December 2003 and ending in December 2004.

The specific threshold values were obtained from a sample of 485 MODIS pixels extracted from burn scars in Argentina, Colombia, and Brazil and covering different months of the year. As said previously, the main goal of the first phase was to reduce commission errors to a minimum, and therefore the selection of thresholds was based on a low percentile of the total pixels classified as burned areas in the sampling sites. The percentile was changed iteratively to test which value provided consistent classification in all study sites and land-cover types being analyzed. The final values are included in Table 2. With these values, $12 \%$ of the sampled pixels were detected as burn areas. This implies a large omission error, but our main goal in this phase was to avoid confusion with other covers.

The final step of the first phase was to eliminate small clusters of pixels. Since the minimum target burn scar was 250 ha, small groups of pixels were not very reasonable and would have created severe noise. Therefore all patches with fewer than five pixels (125 ha) were eliminated. It was expected that the final patches would be greater than this size after the contextual algorithm was applied. 

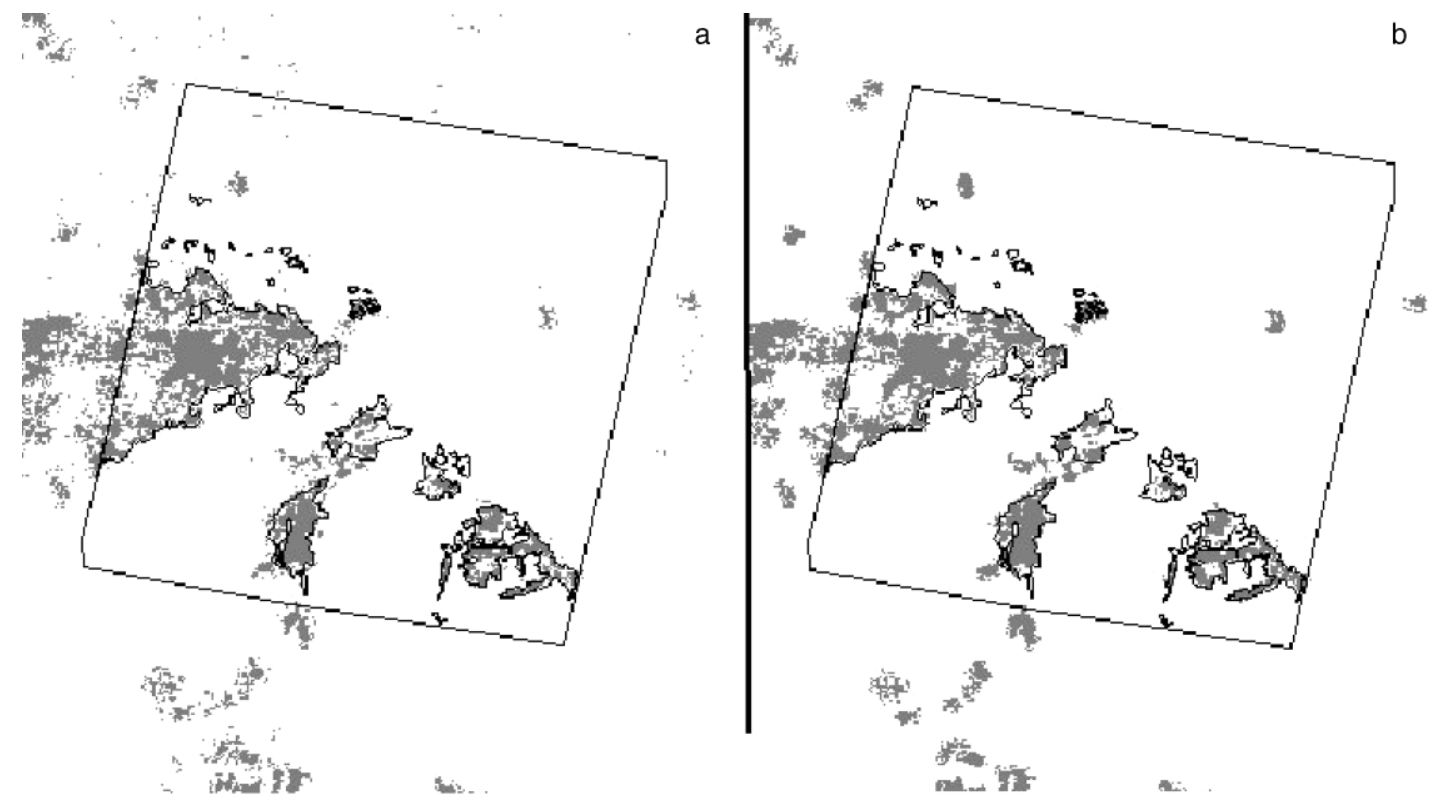

FIG. 1. Effect of changing window size in the regional context algorithm: (a) $3 \times 3$ pixels, (b) $21 \times 21$ pixels. The area shown covers a MODIS image of central Brazil.

Contextual algorithm.-The second step in our processing method was intended to refine the discrimination of burn scars from those areas previously detected as "core" burned pixels. In order to do this, a contextual algorithm was developed to take into account the similarity of neighboring pixels to those previously labeled as burned areas. In this case, the goal was to reduce omission errors by including those pixels that might be less severely burned or those with a weaker charcoal signal.

The criteria to extend the core pixels to their surroundings were based on the geographical and spectral similarity of targeted pixels with those already identified as burned areas. As a criterion of geographical similarity, a maximum distance for inclusion was established, while the spectral criterion to add a pixel to the burned area was based on comparing the BAI values of that pixel with those in the vicinity. The comparison of pixel values with the local neighborhood has been previously used in burned land mapping (Fernández et al. 1997), and it is routinely used in fire detection algorithms (Martín et al. 1999). For this project, the BAI was used as a measure of charcoal similarity, and the criterion to include a pixel was based on whether that pixel had a BAI value above the mean of the surroundings, as defined by a certain window size centered in that pixel. In summary, a pixel would be added to a burn scar when its distance to any pixel in the burn scar was below a certain threshold and when its BAI value was above the mean BAI of the vicinity. Several maximum distances to the core pixels were analyzed (from 3 to $11 \mathrm{~km}$ ) studying their performance against sampled burned areas from which burn perim- eters were available. A similar approach was applied to find out the most convenient window size to extract mean BAI value for estimating the neighborhood patterns. Window sizes from $3 \times 3$ pixels to $21 \times 21$ pixels were tested (Fig. 1). The effects of different window sizes were not evident, although larger windows tended to be more consistent in patchy areas. Therefore, a window of $21 \times 21$ pixels was finally selected.

\section{Analysis}

Geographical patterns of the results were based on latitude and longitude fringes on one hand and land cover types on the other. The former was aimed at providing a zoning analysis of fire occurrence, while the latter was intended to offer a global view of the most affected ecosystems. The land cover layer was extracted from the MOD12Q1 (v.4) standard MODIS product, generated by the University of Boston (available online). ${ }^{21}$ This product was generated from MODIS data from the period 1 January 2001 to 31 December 2001, and it is based on reflectance data, spectral vegetation indices and surface texture information. The product is offered for different land-cover classification systems. We selected the classification system defined by the International Geosphere Biosphere Program (IGBP) land cover project (Belward 1996), which includes 17 global land cover categories. The product was available in Interrupted Goode Homolosine projection, thus facilitating the comparison with the AQL2004 results. The world mosaic was downloaded, and the Latin html $\rangle$

${ }^{21}\langle\mathrm{http}: / /$ www-modis.bu.edu/landcover/userguidelc/intro. 


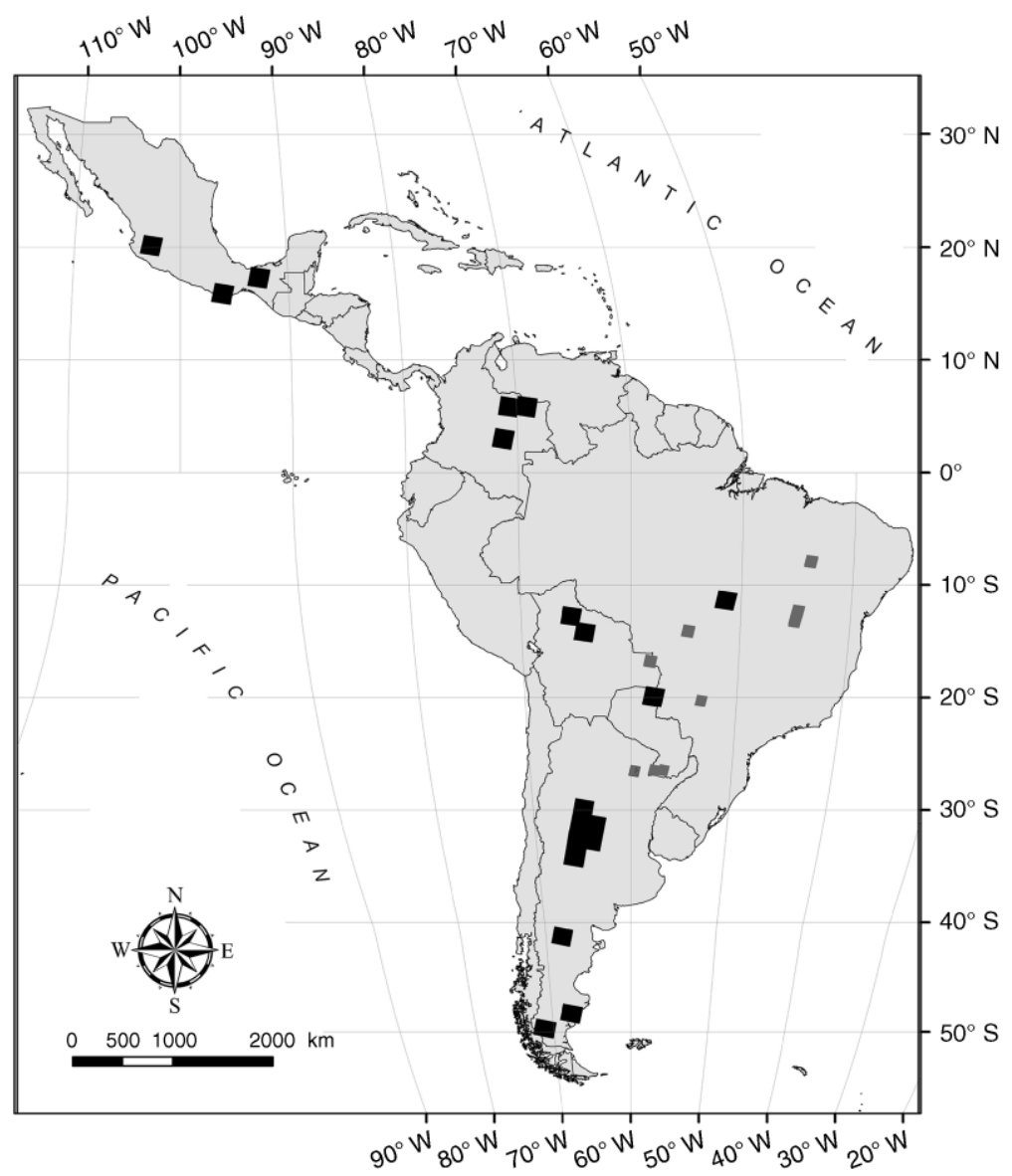

FIG. 2. Validation sites where high-resolution satellite data were processed. Dark boxes refer to Landsat-TM/ETM+data; gray boxes are CBERS images.

American region was extracted for further analysis (available online). ${ }^{22}$

\section{Assessment}

Accuracy assessment is a critical component of any method to generate spatial information, but it has been greatly emphasized in studies based on remotely sensed images (Congalton and Green 1999). Most local studies include sound procedures to validate the results, based on field sampling or higher spatial resolution imagery. However, this task is especially complex when generating global products since it involves covering large areas with a wide diversity of potential errors. However, the importance of validating global variables is acknowledged by most global scope projects, and networks of scientists are built upon those projects to ensure accuracy assessment. For instance, the MODIS program has a specific task group dedicated to product validation (Morisette et al. 2002), and the team involved in the MODIS burned-land product has already produced an

${ }^{22}\langle$ http://duckwater.bu.edu/lc/mod12q1.html $\rangle$ extensive validation protocol for some study sites within the SAFARI campaign (Roy et al. 2005a). In burnedland mapping, neither the GBA2000 nor the GLOBSCAR project have undertaken a full validation strategy, although some efforts have been proposed for retrospective validation (Boschetti et al. 2006).

The AQL2004 project was designed by a network of local scientists, therefore product validation was considered a priority from the beginning of the project. Considering the financial constraints of the project, the validation was based on high-resolution satellite images that were donated by regional space agencies. The Argentinean agency CONAE (Comisión Nacional de Actividades Espaciales), the Brazilian agency INPE (Instituto Nacional de Pesquisas Espaciaes), and the Mexican agency CONABIO (Comisión Nacional para el Conocimiento y Uso de la Biodiversidad) provided Landsat-TM/ETM+ (30-m pixel size), CBERS (ChinaBrazil Earth Resources Satellite; $20 \mathrm{~m}$ ), and SPOT (20 $\mathrm{m})$ images, respectively, for the validation of the burnscar product. Fig. 2 shows the images that were used for validation of the whole project. 
The validation itself was based on visual interpretation of those higher resolution images from which fire perimeters were derived. The images were previously converted to the Goode Homolosine Projection, to match the MODIS input data. Visual analysis has been widely used for discriminating burn scars (Roy et al. $2005 a$ ), since burned areas generally have a distinct color and shape pattern. Visual interpretation was digitized on screen, and vector files were extracted to cross tabulate with results from our burned land algorithm to generate confusion matrices (agreement between the results and the high-resolution data). Common measures of accuracy and error (omission and commission errors, and global accuracies; Congalton and Green 1999) were computed.

Considering the great differences in spatial resolution between the two sets of images (MODIS, $500 \mathrm{~m}$ and TM/ETM/CBERS 20-30 m), the interpretation of the omission and commission errors from this cross tabulation must be done cautiously, since some of them should in fact be associated to misregistration or differences in spatial coverage of both data sets. To reduce the impact of these problems, other validation techniques were carried out. An alternative to validate our burned area results was to extract the proportion of burned area in both MODIS and high-resolution images for a grid of regular cells (in this case, a $5 \times 5 \mathrm{~km}$ grid was selected). This approach has been suggested by other authors (Roy et al. 2005a) and facilitates a spatial statistical assessment that is less affected by registration problems or differences in pixel size. This approach was restricted to those images with a significant proportion of burned area. Otherwise, the comparison is statistically meaningless.

Additionally, to test the effect of fire size on the quality of discrimination, a global comparison between the number of burn patches detected by MODIS and those detected by high-resolution images was performed. In this case, we completed that analysis only for the validation sites that have a great number and diversity of burn scars. Also, we considered that a burn patch was detected when at least $10 \%$ of its area was identified in the MODIS images.

Finally, our results were also compared to the active fires detected by the MODIS program. Although they are produced by the same sensor, active-fire products are independent from burned-land products because they are based on a completely different physical principle (Justice et al. 2002). Active fire detection is based on middle infrared bands (3-5 $\mu \mathrm{m}$ wavelength), which are the most sensitive to detect high-temperature targets, and therefore the fires are only detectable when they are active, while burned-land maps are based on postfire conditions. Therefore, since the two products are independent, their agreement indicates a greater likelihood of accuracy (Roy et al. 2005b). For this project, all active fires detected by the MODIS program (Giglio et al. 2003) for 2004 were downloaded and grouped in $25 \times$
$25 \mathrm{~km}$ cell sizes (data available online). ${ }^{23}$ The number of active fires per month was compared with the total burned area discriminated by our algorithm. A total number of 29175 cells was obtained for South America and 5174 for Mexico and Central America, after removing those where water covered more than $95 \%$ of the cell area.

\section{Results}

\section{Geographical analysis of burned areas}

Fig. 3 includes the summary of the project results, with the geographical distribution of burned areas discriminated in the different periods of the MODIS 32-day composites. A total number of 14446 burned land polygons were identified by the AQL2004 algorithm, which covered an area of $153215 \mathrm{~km}^{2}$. The most affected countries were Argentina, Brazil, Colombia, Bolivia, and Venezuela, which make up $90 \%$ of the total area burned. In relative terms, the AQL2004 results show that the most affected countries were Cuba, Colombia, Bolivia, Venezuela, and Argentina, all of which had $>1.2 \%$ of the national territory burned (Table 3). The most continuous areas affected by biomass burnings are the savanna regions of Colombia and Venezuela, the boundaries of the evergreen forest in Brazil and Bolivia, and the Central and Northern provinces of Argentina. Central Cuba and the southern part of Guatemala were also noticeable. Scattered patches were observed in Mexico and Chile.

The burned areas affected a wide variety of land-cover types, but the herbaceous areas presented a much higher impact. In fact, grasslands, woody savannas, and savannas accounted for $63 \%$ of the total burned area detected in this project. For these categories the fire affected around $1.5 \%$ of the total area they cover in the region. Only croplands represented a higher proportion, with more than $2 \%$.

The evergreen forest showed the higher ratio between the percentage of total area covered in the region and the percentage of total burned area $(36 \%: 7.22 \%)$, while the lower ratio was found for croplands and grasslands (8.04\%:17.21\%). This ratio implied that the percentage of burned area in evergreen forest was much lower than the total percentage of area covered by this category, being the opposite in the case of grasslands. In other words, according to our results, biomass burning had much less impact in evergreen forests than in grasslands. However, from a fire-emissions point of view, the importance of evergreen forests is obviously greater because they have much higher biomass loads.

\section{Seasonal trends}

Biomass burning followed seasonal dry periods in 2004, as it might be expected. Grasslands and herbaceous areas in the Northern Hemisphere were burned

${ }^{23}\langle$ http://maps.geog.umd.edu/firms/shapes.htm $\rangle$ 


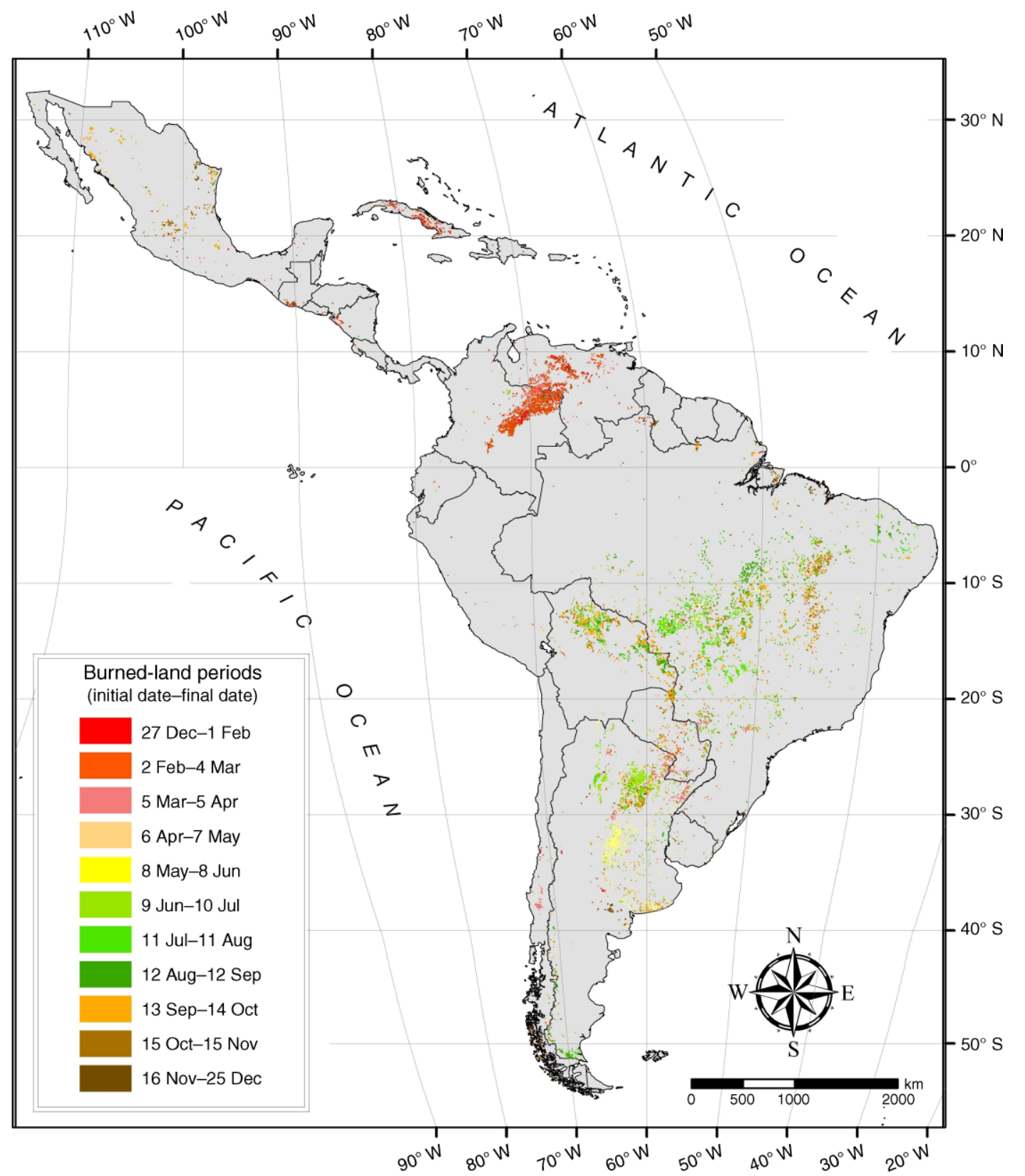

FIG. 3. Geographical distribution of burn scars for the different MODIS 32-day composites, December 2003 through December 2004.

mainly between January and the middle of March, while in the Southern Hemisphere the peak of fire occurrence was observed between July and September (Fig. 3). Seasonal distribution of burned areas for the most affected countries can be observed in Fig. 4. A clear burn-land peak during the dry season was observed for Colombia and Venezuela in the Northern Hemisphere (February), and Brazil and Bolivia in the Southern Hemisphere (September-October). Mexico had low fire occurrence in 2004, and the most affected months do not clearly match the driest periods. Argentina presented an unexpected pattern, too, since most burned areas were detected between March and June.

The most common land covers in burned areas are shown in Fig. 5 for the different periods of analysis. The impact of fire on herbaceous vegetation was distributed throughout the year, although in the dry season (February in the Northern Hemisphere and AugustSeptember in the Southern Hemisphere) it accounted for an even larger percentage. An important percentage of 
TABLE 3. Burned areas mapped in the AQL2004 project in the different 32-day periods.

\begin{tabular}{|c|c|c|c|c|c|c|c|c|c|c|c|c|}
\hline \multirow[b]{2}{*}{ Country } & \multicolumn{12}{|c|}{ Burned area $\left(\mathrm{km}^{2}\right)$} \\
\hline & $\begin{array}{l}27 \text { Dec- } \\
1 \text { Feb }\end{array}$ & $\begin{array}{l}2 \text { Feb- } \\
4 \text { Mar }\end{array}$ & $\begin{array}{l}5 \mathrm{Mar}- \\
5 \mathrm{Apr}\end{array}$ & $\begin{array}{l}6 \text { Apr- } \\
7 \text { May }\end{array}$ & $\begin{array}{l}8 \text { May- } \\
8 \text { Jun }\end{array}$ & $\begin{array}{l}9 \text { Jun- } \\
10 \mathrm{Jul}\end{array}$ & $\begin{array}{l}11 \mathrm{Jul}- \\
11 \mathrm{Aug}\end{array}$ & $\begin{array}{l}12 \mathrm{Aug}_{-} \\
12 \mathrm{Sep}\end{array}$ & $\begin{array}{l}13 \text { Sep- } \\
14 \text { Oct }\end{array}$ & $\begin{array}{l}15 \text { Oct- } \\
15 \text { Nov }\end{array}$ & $\begin{array}{l}16 \text { Nov- } \\
25 \text { Dec }\end{array}$ & $\begin{array}{l}\text { Total, } \\
\text { all periods }\end{array}$ \\
\hline Argentina & 542 & 1357 & 2953 & 6851 & 6803 & 7285 & 2701 & 1700 & 3321 & 667 & 1000 & 35178 \\
\hline Belize & 0 & 0 & 0 & 0 & 0 & 0 & 0 & 0 & 0 & 11 & 0 & 11 \\
\hline Bolivia & 42 & 156 & 29 & 107 & 98 & 265 & 2139 & 5632 & 6453 & 1274 & 80 & 16274 \\
\hline Brazil & 298 & 332 & 2135 & 2012 & 2010 & 5233 & 9744 & 12510 & 12687 & 4611 & 1560 & 53131 \\
\hline Chile & 56 & 256 & 671 & 312 & 109 & 66 & 18 & 80 & 223 & 62 & 69 & 1921 \\
\hline Colombia & 4532 & 12789 & 1602 & 0 & 0 & 86 & 32 & 85 & 134 & 10 & 180 & 19449 \\
\hline Costa Rica & 0 & 15 & 34 & 0 & 0 & 0 & 0 & 0 & 0 & 0 & 0 & 48 \\
\hline Cuba & 1261 & 645 & 1052 & 54 & 0 & 0 & 19 & 0 & 0 & 120 & 170 & 3320 \\
\hline $\begin{array}{r}\text { Dominican } \\
\text { Republic }\end{array}$ & 23 & 0 & 0 & 0 & 0 & 0 & 0 & 0 & 0 & 0 & 0 & 23 \\
\hline Ecuador & 18 & 0 & 13 & 12 & 0 & 0 & 14 & 0 & 31 & 28 & 0 & 116 \\
\hline El Salvador & 30 & 0 & 0 & 0 & 0 & 0 & 0 & 0 & 0 & 0 & 21 & 51 \\
\hline Guatemala & 263 & 159 & 40 & 0 & 0 & 0 & 0 & 0 & 0 & 24 & 182 & 668 \\
\hline Guyana & 54 & 26 & 0 & 0 & 0 & 0 & 0 & 11 & 0 & 83 & 159 & 332 \\
\hline Haiti & 0 & 0 & 0 & 0 & 0 & 0 & 0 & 0 & 0 & 17 & 0 & 17 \\
\hline Honduras & 23 & 0 & 20 & 0 & 0 & 0 & 0 & 24 & 0 & 0 & 42 & 107 \\
\hline Mexico & 234 & 89 & 262 & 161 & 19 & 32 & 106 & 62 & 1907 & 1295 & 664 & 4829 \\
\hline Nicaragua & 223 & 40 & 19 & 0 & 0 & 0 & 26 & 0 & 0 & 9 & 30 & 347 \\
\hline Panama & 0 & 0 & 0 & 0 & 0 & 13 & 0 & 0 & 0 & 0 & 0 & 13 \\
\hline Paraguay & 46 & 753 & 877 & 24 & 24 & 162 & 57 & 518 & 1411 & 461 & 0 & 4333 \\
\hline Peru & 28 & 12 & 23 & 16 & 15 & 14 & 9 & 20 & 28 & 19 & 5 & 188 \\
\hline Suriname & 0 & 12 & 10 & 0 & 0 & 0 & 0 & 0 & 39 & 8 & 14 & 81 \\
\hline $\begin{array}{l}\text { Trinidad and } \\
\text { Tobago }\end{array}$ & 0 & 8 & 8 & 0 & 0 & 0 & 0 & 0 & 0 & 0 & 0 & 16 \\
\hline Uruguay & 6 & 12 & 67 & 9 & 9 & 7 & 37 & 30 & 34 & 24 & 27 & 260 \\
\hline Venezuela & 3567 & 6384 & 2041 & 0 & 0 & 41 & 0 & 0 & 0 & 55 & 414 & 12501 \\
\hline Total & 11246 & 23041 & 11854 & 9557 & 9087 & 13203 & 14901 & 20670 & 26266 & 8777 & 4613 & 153215 \\
\hline
\end{tabular}

Notes: Dates (32-day measured periods) are shown as initial day and month through final day and month, beginning in December 2003 and ending December 2004. AQL2004 is Area Quemada en Latinoamerica (burned land areas in Latin America) for 2004.

the burned land was found in agricultural areas (17\%). Shrubs were the dominant land cover in $8 \%$ of the burned area and they were distributed evenly throughout the year. The forested areas covered almost $10 \%$ of the burn scars. From those areas, evergreen forests burned more than deciduous forest, although important proportions of deciduous forest were also burned in June/July and September.

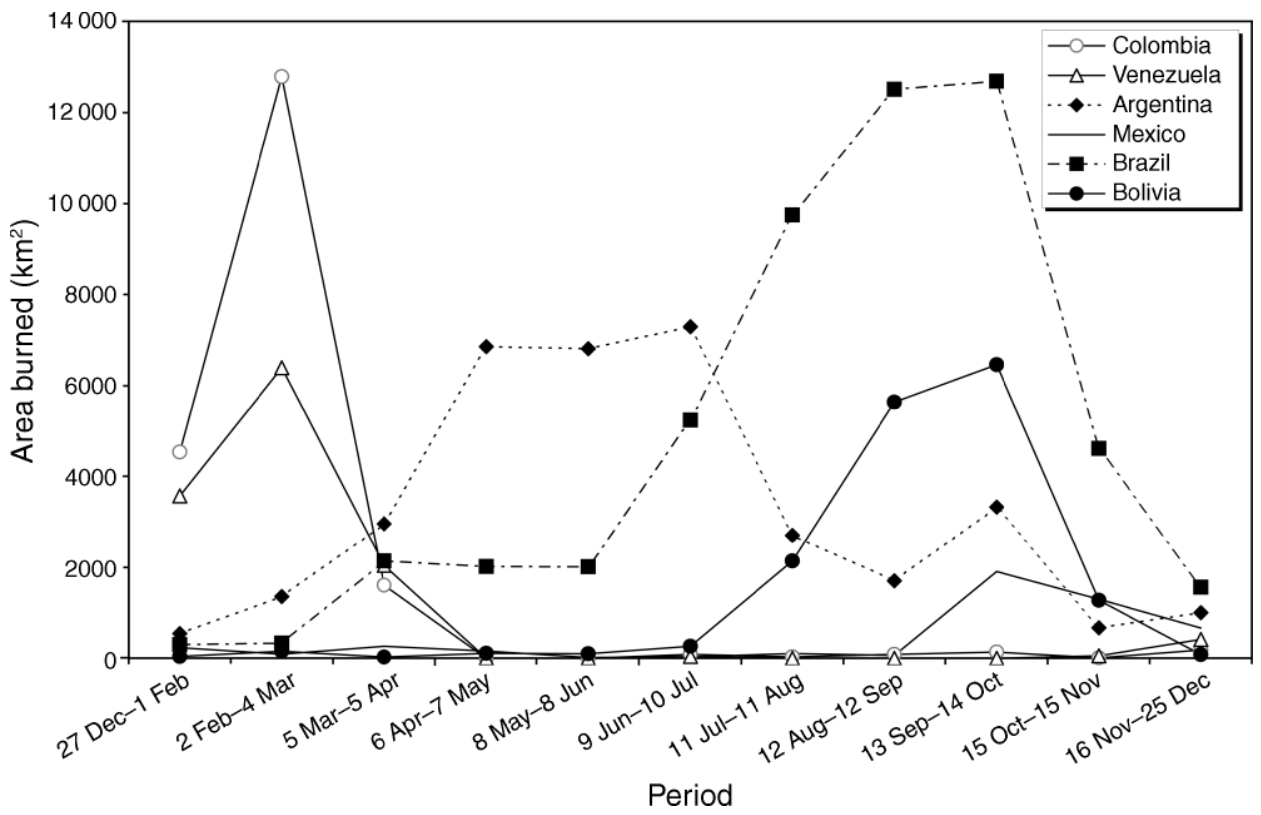

FIG. 4. Seasonal distribution of burned areas for different Latin American countries, December 2003 through December 2004. 


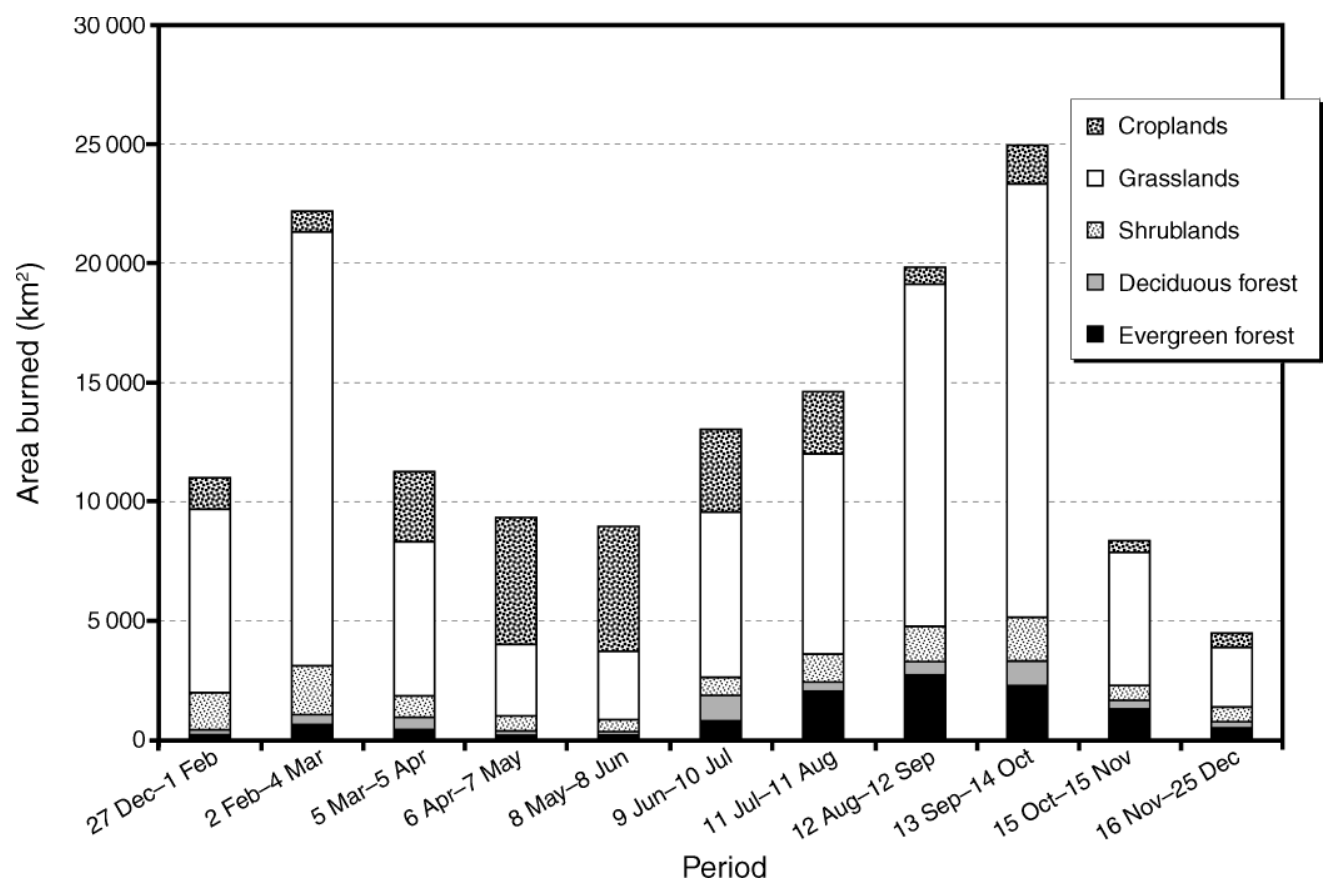

FIG. 5. Monthly burned areas for different land covers, December 2003 through December 2004.

Assessment

Validation of the AQL2004 algorithm results were performed with both higher resolution data and active fires detected by the thermal channels of the MODIS instrument. We have used the term agreement, instead of accuracy, since the disagreements between reference data (high-resolution images or active fire detections) can not always be considered errors, as it will be explained in the Discussion section, although they provided an initial assessment of the project performance.

The first assessment was based on cross-tabulation analysis of MODIS and high-resolution images. Fig. 6

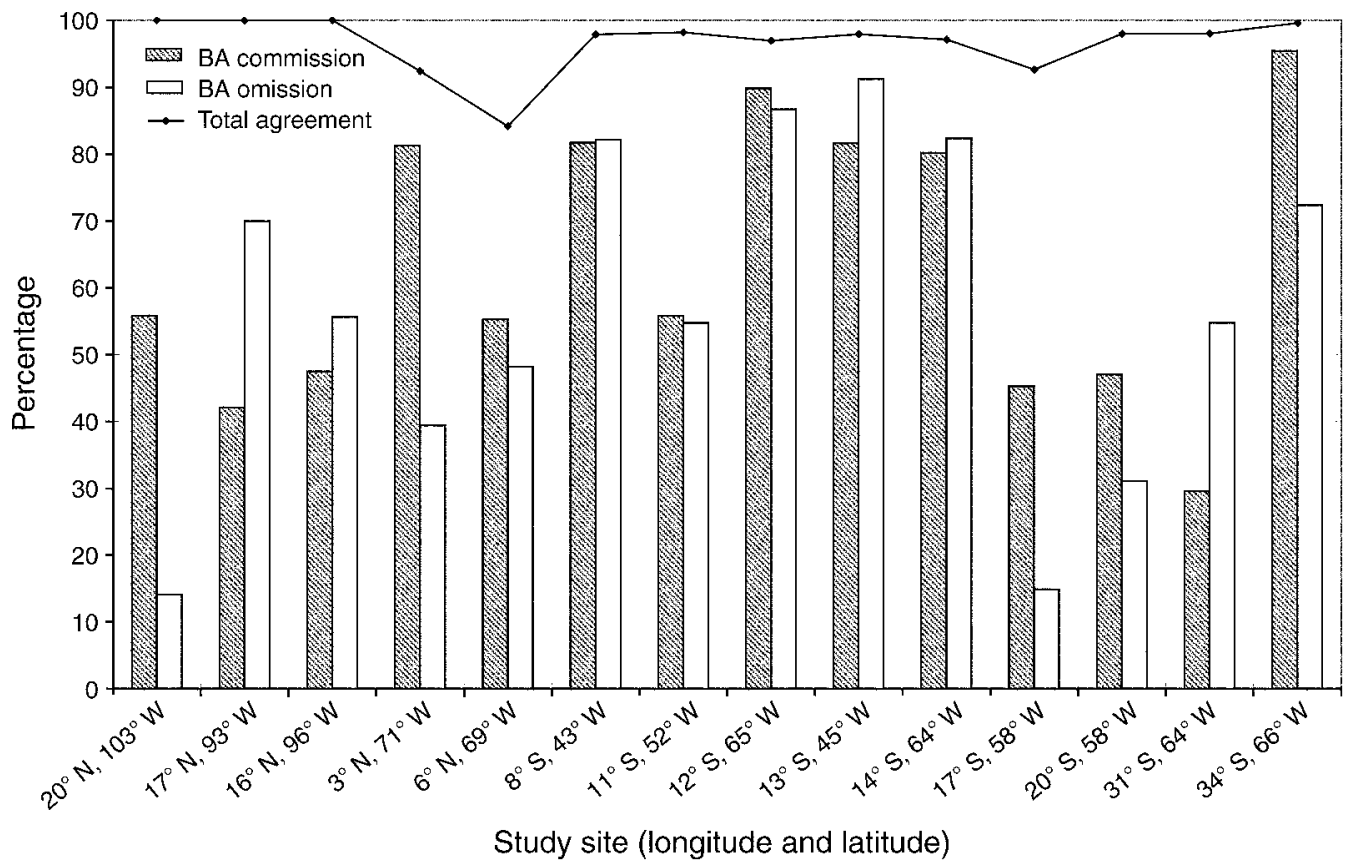

Fig. 6. Validation results by study site. Total percentage agreement (black line) refers to both burned and unburned classes, while bars refer to omission and commission percentage disagreements of the burned area (BA) exclusively. 


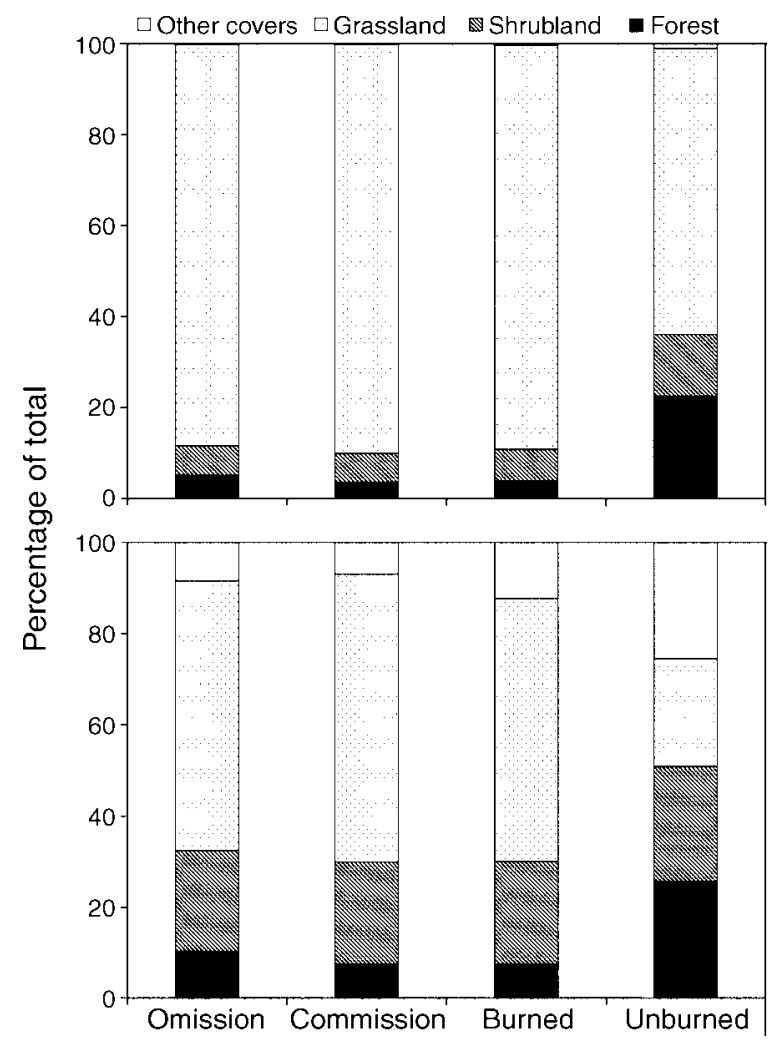

FIG. 7. Validation results by main land covers (upper panel) as a percentage of total area in different agreement conditions and (lower panel) as a percentage of total area of different land covers. Burned and unburned categories refer to areas that were well detected as burned or unburned.

includes total agreement between the two sources, as well as commission and omission disagreements for burned land discrimination as a proportion of areas observed in high resolution images (Landsat or CBERS).

Total agreement, as defined by both the burned and unburned area discrimination, was very high in all study sites, since in most validation sites the vast part was covered by unburned areas that were properly discriminated as such. Values were generally higher than $95 \%$, with a global value of $96 \%$ for all validation sites. However, burned-land discrimination showed high omission and commission disagreements in most validation sites, with a total value of $47 \%$ commission and $63 \%$ of omission with respect to high-resolution burned areas. The disagreements between the two sources were especially high between $8^{\circ} \mathrm{S}$ and $14^{\circ} \mathrm{S}$ of the Southern Hemisphere, and central and Southern regions of Argentina (Fig. 6). The lower omission errors were found for Mexico and the border between Brazil and Bolivia. It is important to remark that omission and commission disagreements were generally balanced in the different study areas, which made it possible to obtain more confident area estimations from our results.
Areas covered by herbaceous vegetation offered the lowest agreement across all validation sites, although they were also the most frequent (Fig. 7). We observed $87 \%$ of all omission and $89 \%$ of commission disagreements in herbaceous covers (grass and crops), mostly associated with croplands in the latter case. Grasslands offered higher agreement in tropical regions of Colombia and Brazil than in temperate areas of Argentina; although the amount of burned area in herbaceous vegetation was also lower in this latter region. Forest showed a higher proportion of well discriminated unburned areas and had a significant, lower ratio of omission and commission errors.

An alternative view of validation can be observed in Fig. 8, which shows two examples of the spatial validation procedure. A cross tabulation between burn scars discriminated in the MODIS and the highresolution images made it possible to analyze the spatial distribution of agreements and disagreements between the two sources As it can be observed in Fig. 8a, c, the disagreements are spatially contiguous with the matched pixels, and therefore they should be more related to boundary effects than to an incorrect discrimination. The scatter plots with the proportion of burned areas in both high and low resolution data for different $5 \times 5 \mathrm{~km}$ cells (Fig. 8b,d) provided a complementary view of the spatial agreements between the two data sources. In both cases, the correlations between the two sources are highly significant, but the slope is closer to 1 in the Brazilian site, mainly covered by forested areas.

Table 4 classifies the performance of burn-scars detection by the AQL algorithm considering fire size. As it could be expected, small patches have a low detection rate. Below 1500 ha, the rate fluctuates from $75 \%$ to just $50 \%$ of all burn patches. Above that threshold the detections significantly improve, going up to $100 \%$ in most cases. The differences in area detected between MODIS and high-resolution images are notable, but it is important to emphasize that the algorithm provides a good spatial assessment of burns in the region, at least for medium-to-large fire sizes.

The final validation exercise was focused on comparing burn scars and active fires. A $25 \times 25 \mathrm{~km}$ grid cell was used in this case for extracting both sources of fire information. The proportion of pixels within each cell in both sources was correlated for the entire region. Table 5 offers the results for South America and Mexico. The trends show a global tendency of agreement between the two data sources with positive correlations for most periods. The mean correlation between the two sources of data was $0.229(P<0.001)$. The peaks of fire occurrence, in January-February and August-September, also offered the highest correlations, especially the former. In Central America, the correlations were generally lower. Differences in agreement values were observed between different land covers. Grasslands presented the highest correlations in the dry periods of both hemispheres, while forested areas and crops offered 
a

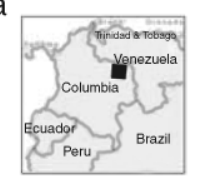

Commission Burned area Unburned area Omission
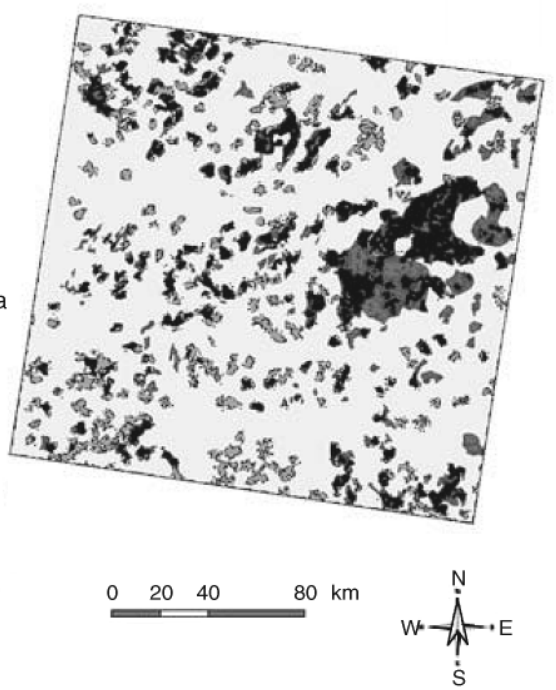

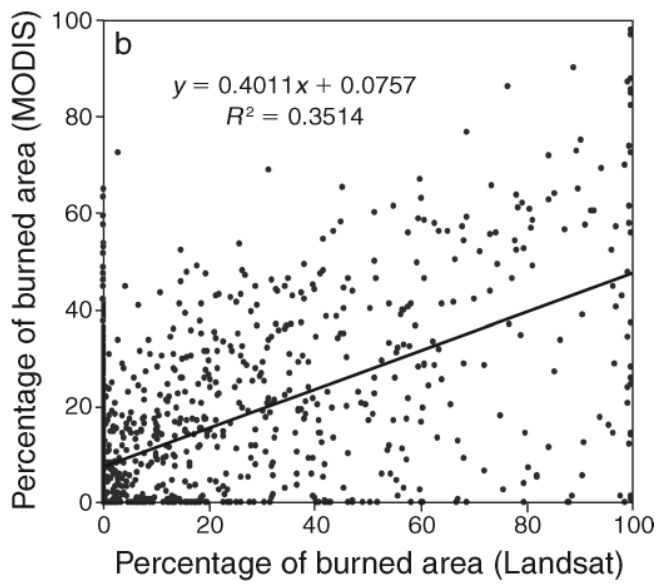

C
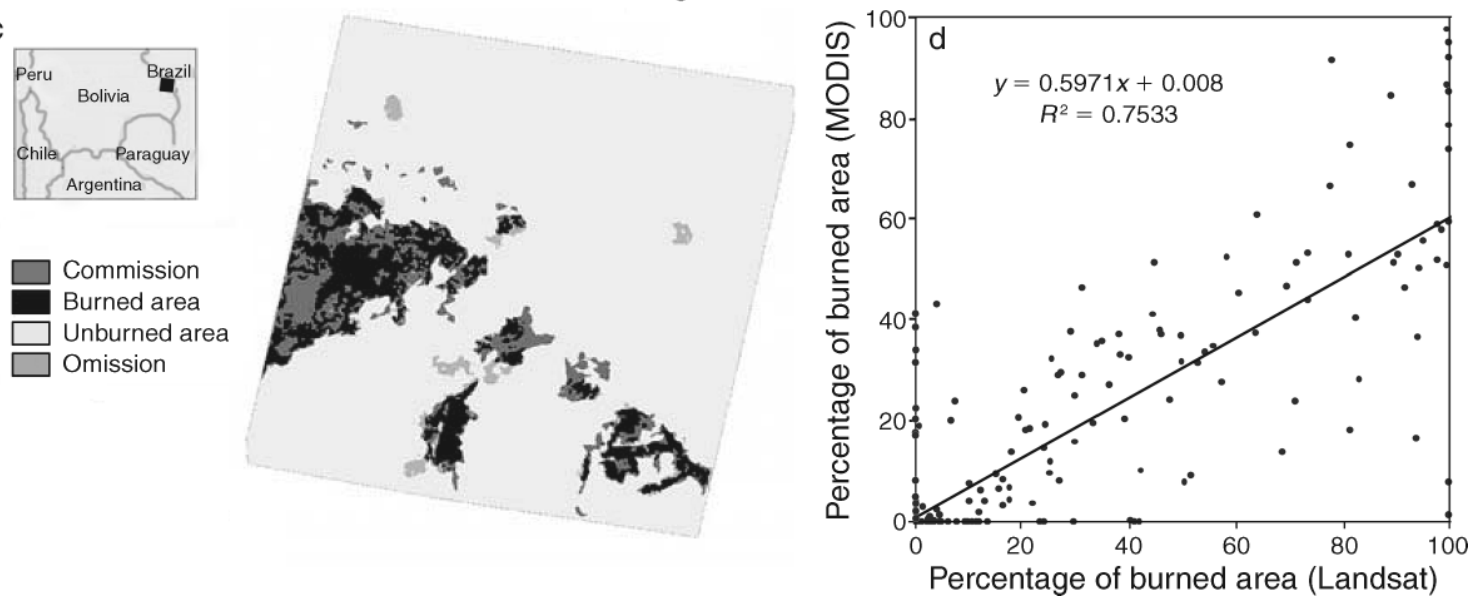

FIG. 8. Two examples of the validation procedure: panels (a) and (c) show cross-tabulated images of burned areas in Landsat and MODIS; panels (b) and (d) are scatter graphs derived from $5 \times 5 \mathrm{~km}$ grids with the percentages of burned area identified by both sources. The site in panels (a) and (b) is eastern Colombia; the site for panels (b) and (d) is western Brazil.

low accuracy at the beginning of the year, but the correlations increase from February to August. Shrubs showed better $r$ correlation at the beginning of the time series, but show poor agreement for the months of March-October.

\section{Discussion And Conclusions}

The AQL2004 project generated a burned land map of Latin America for 32-day periods covering 2004. The total estimation of burned area for the region (153215 $\mathrm{km}^{2}$ ) was close to that obtained from similar projects for 2000, when the GBA2000 project estimated $137000 \mathrm{~km}^{2}$ and GLOBSCAR $162774 \mathrm{~km}^{2}$, as well as with the mean burned area calculated for the 1997-2004 period from active fire detections $\left(200000 \mathrm{~km}^{2}\right.$; van der Werf et al. 2006). To obtain similar estimations, in spite of using very different sensors (SPOT/VEGETATION for the GBA2000 project and ATSR for GLOBSCAR) or different data sources (active fires in the van der Werf et al. [2006] study), confirms the robustness of the burned-area estimations.

At a local scale, the estimations should be taken with more caution, according to the results of our assessment exercise and the work of other authors. For instance, Armenteras et al. (2005) found the burned area to be about one-third of the AQL2004 results in their 2000 and 2001 analysis of the Colombian savannas using Landsat images, although their data do not refer to the whole country, as AQL2004 does. In any case, their study showed a similar temporal pattern to the one found for AQL2004 data. Conversely, according to deforestation rates of Brazil and its close association to burnings, as well as the use of fire for some crops (sugar cane), the estimation of burned areas for the AQL2004 project should be considered very conservative, since some sources estimate the annual burned area in this country up to more than $500000 \mathrm{~km}^{2}$ (A. Setzer, personal observation). 
TABLE 4. Number of burn patches detected by the AQL algorithm vs. those observed in high-resolution (HR) images.

\begin{tabular}{|c|c|c|c|c|c|}
\hline \multirow[b]{2}{*}{ Fire size (ha) } & \multicolumn{2}{|c|}{ No. burn patches } & \multirow[b]{2}{*}{ HR estimation (ha) } & \multirow[b]{2}{*}{ AQL estimation (ha) } & \multirow[b]{2}{*}{ Detected fires (\%) } \\
\hline & Observed & Detected & & & \\
\hline $250-500$ & 54 & 27 & 20515 & 6078 & 50.0 \\
\hline $500-750$ & 30 & 20 & 17885 & 7043 & 66.7 \\
\hline $750-1000$ & 28 & 23 & 23480 & 12686 & 82.1 \\
\hline $1000-1250$ & 16 & 9 & 17713 & 6455 & 56.3 \\
\hline $1250-1500$ & 16 & 12 & 21016 & 8940 & 75.0 \\
\hline $1500-1750$ & 13 & 12 & 20152 & 10994 & 92.3 \\
\hline $1750-2000$ & 8 & 6 & 13892 & 4505 & 75.0 \\
\hline $2000-2250$ & 11 & 9 & 22061 & 11614 & 81.8 \\
\hline $2250-2500$ & 9 & 8 & 19823 & 5727 & 88.9 \\
\hline $2500-2750$ & 7 & 7 & 16397 & 7895 & 100.0 \\
\hline $2750-3000$ & 9 & 8 & 23571 & 9630 & 88.9 \\
\hline $3000-3500$ & 12 & 10 & 35243 & 14034 & 83.3 \\
\hline $3500-4000$ & 8 & 8 & 26934 & 10748 & 100.0 \\
\hline $4000-10000$ & 15 & 14 & 98215 & 36917 & 93.3 \\
\hline$>10000$ & 14 & 14 & 493586 & 252200 & 100.0 \\
\hline Total & 250 & 187 & 870483 & 405466 & 74.8 \\
\hline
\end{tabular}

The case of Mexico requires a further examination, since it offered a very low percentage of burned areas compared to the size of the country. Although national statistics do not match AQL2004 estimations in absolute numbers, they clearly show a decrease in fire activity for 2004. In fact, that year had the lowest fire occurrence in Mexico in the period 1998-2005 according to the Mexican Forest Service. This was caused by humid conditions, especially at the beginning of the year. The seasonal trends of expected fire occurrence did not agree with the observed trends, since in Mexico the burned land areas were mainly detected during the fall, which is ordinarily wetter than early spring, although the particular weather patterns of 2004 were not available for validation of this hypothesis. Confusion between agricultural crops and wildland fires may explain this temporal trend since many burn scars were located in agricultural areas. However, there is not much information on agricultural burnings in the country.

The validation of the results was done with four different methods that generally agreed, although various uncertainties in the reference data preclude deriving definitive conclusions. On one hand, the comparison of high resolution data (Landsat or CBERS) with MODIS data implies potential problems caused by misregistration or boundary effects related to the great difference of pixel sizes between the two sources. In this regard, the comparison between burn patches in our results and high-resolution data shows very adequate agreement, especially when fires are larger than 1500 ha.

Another source of discrepancy between MODIS and high-resolution images was associated with the different time periods they refer to. Our input data were 32-day composite periods. Therefore, when using a Landsat image from after the end of the composite period, it was difficult to assess whether, for instance, the burned areas not detected by the AQL algorithm were in fact omission errors or rather fires that occurred between the end of the 32-day composite period and the time of Landsat image acquisition. An opposite situation would occur when the Landsat image was acquired within the 32-day composite period, but in this case it would affect the commission errors.

Finally, the relation between hot spots and burn scars improved the spatial analysis of errors, but it can not be

TABLE 5. Pearson $r$ correlation values between burn scars and active fires for the different 32-day study periods.

\begin{tabular}{|c|c|c|c|c|c|c|}
\hline \multirow[b]{2}{*}{ Period } & \multicolumn{5}{|c|}{ South America } & \multirow{2}{*}{$\frac{\text { Mexico }}{\text { All covers }}$} \\
\hline & Forest & Shrubs & Grasslands & Crops & All covers & \\
\hline 27 Dec-1 Feb & 0.045 & 0.376 & 0.492 & 0.035 & 0.367 & 0.020 \\
\hline 2 Feb-4 Mar & 0.265 & 0.450 & 0.453 & 0.423 & 0.383 & 0.236 \\
\hline $5 \mathrm{Mar}-5 \mathrm{Apr}$ & 0.071 & 0.119 & 0.309 & 0.096 & 0.233 & 0.069 \\
\hline $6 \mathrm{Apr}-7$ May & 0.033 & -0.002 & 0.103 & -0.042 & 0.022 & 0.056 \\
\hline 8 May-8 Jun & 0.173 & 0.173 & 0.131 & -0.027 & 0.042 & 0.077 \\
\hline 9 Jun-10 Jul & 0.203 & 0.137 & 0.273 & 0.368 & 0.195 & 0.057 \\
\hline 11 Jul-11 Aug & 0.227 & 0.062 & 0.293 & 0.301 & 0.170 & 0.000 \\
\hline 12 Aug-12 Sep & 0.331 & -0.032 & 0.404 & 0.083 & 0.149 & 0.119 \\
\hline $13 \mathrm{Sep}-14 \mathrm{Oct}$ & 0.190 & 0.048 & 0.221 & 0.054 & 0.184 & 0.240 \\
\hline 15 Oct-15 Nov & 0.130 & -0.002 & 0.062 & 0.015 & 0.066 & 0.160 \\
\hline 16 Nov-25 Dec & 0.119 & 0.130 & 0.069 & 0.040 & 0.065 & 0.237 \\
\hline
\end{tabular}

Note: Study periods are shown as initial day and month through final day and month. 
properly considered a reliable validation, as detected active fires refer to the specific time of the satellite overpass, and it may miss those that occurred at other day or night periods.

The agreements between our results and both sets of data can be globally considered as acceptable, considering the project constraints. Global agreement (both burned and unburned areas) was very high, and omission and commission disagreements were generally balanced in the different validation sites. The most spatially comprehensive validation of our results was based on comparing active fire detections and burned area, although these two products are conceptually different (Giglio et al. 2006). The global correlation between these two sources $(r=0.229)$ was very significant, showing common spatial patterns of fire occurrence. This Pearson $r$ correlation is higher than those measured for similar global burned-land products. For instance, Boschetti et al. (2004) computed for the Latin American region a Pearson $r$ value of 0.013 between the results of the GBA2000 burned land areas and the active fires derived from ATSR sensor on board the ERS satellite. The $r$ value was even lower for the relationship between GLOBSCAR and active fires (-0.003), in spite of being derived from the same ATSR sensor.

However, for local regions, our assessment exercise also showed that additional efforts are required to adapt the global algorithm to specific land cover or climatic regions, as well as to explore potential improvements with other standard MODIS products. The main potential sources of errors for the AQL2004 project can be related to the limitations of input data, the global character of the algorithm, and the great ecological diversity of the region.

One of the most important limitations of our input data for burned-land mapping is the length of 32-day MODIS composites. In fact, the herbaceous vegetation showed the lower agreement with high-resolution data, on one hand because commission problems were observed because of changes from green areas to dark soils after harvesting. When referring to omission errors, the postfire char signal of grasslands is the less permanent among land covers, and therefore the use of long compositing periods, such as the 32 days used in this project, may be responsible for lower agreements with observed burn scars in high-resolution images. This effect of image frequency on discrimination of burn scars has been observed in other studies from tropical regions, where the carbon signal has almost disappeared within a few weeks after the fire (Trigg and Flasse 2000, Armenteras et al. 2005). Regarding the angular effects on the 32-day MODIS composite, the use of the MOD43 product, which includes a BRDF correction, may be more advisable as it has already observed by other authors (Roy et al. 2005b).

Development of local algorithms is another line of potential improvement of the AQL2004 project. The results from Mexico and Patagonia, for instance, show
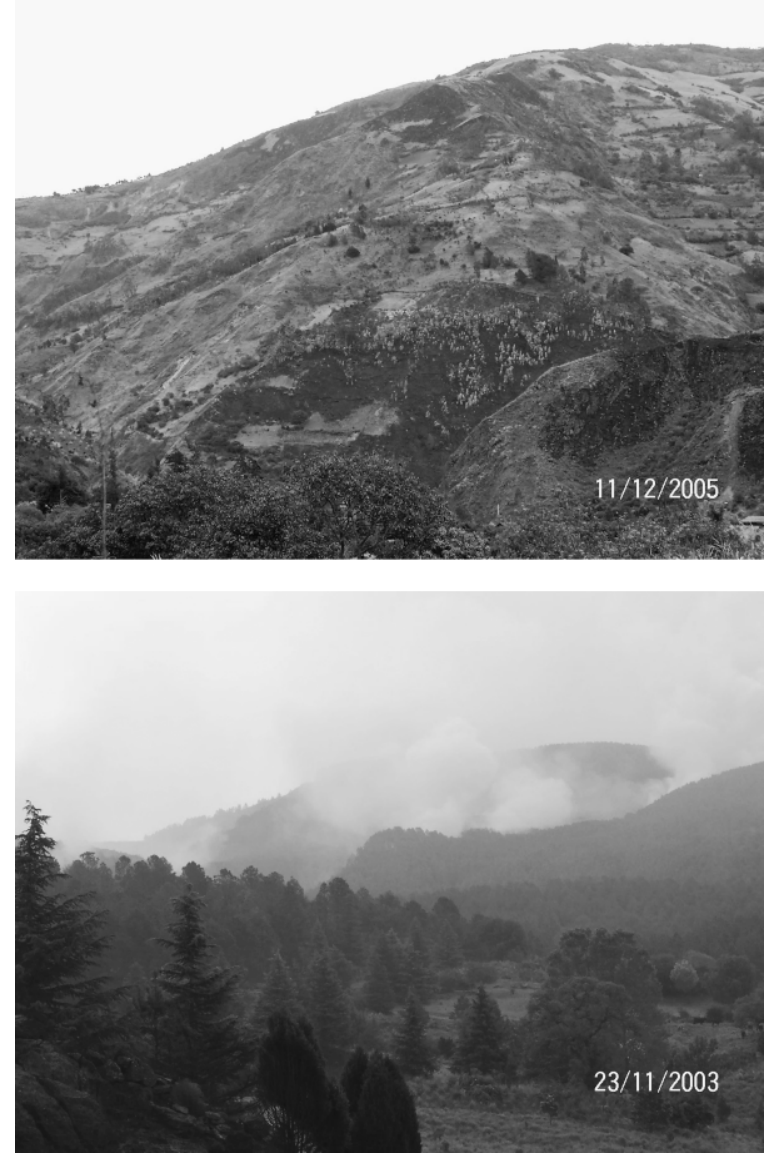

Plate 1. (Top) Recent fires in the Ecuadorian Andes. Burn areas in wet zones of the tropical Andes region tend to have small sizes and create a patchy mosaic. Photo credit: E. Chuvieco, December 2005. (Bottom) Active fires in the interior sierras of Cordoba Province (Argentina). A mixture of pine plantations and natural forest was affected by this fire, in one of the driest summer seasons on record. Photo credit: E. Chuvieco, November 2003.

promising opportunities for developing thresholds or new spectral indices that may be better adapted to the particular soils or vegetation characteristics of the region. Preliminary analysis in Patagonia and Central Buenos Aires in Argentina with "local tuned" algorithms showed better results that those obtained with the global AQL2004 algorithm, but they could not be easily generalized.

We have already commented on the importance of having a systematic evaluation of burned areas in the region. From a global emission estimation point of view, Latin America during the period of 1997-2004 accounted for $5.81 \%$ of the total burned area and $15.77 \%$ of the total biomass burning carbon emissions, and it had an emission ratio more than three times higher than Africa for the same period (van der Werf et al. 2006).

On the other hand, wildland fires are still the main factor of land-use change in the region. Fire is used to remove vegetation in the first phase or after logging, 
then causing a permanent degradation in many areas previously covered by evergreen forest (Cochrane et al. 1999).

Finally, the ecological impacts of fire need to be addressed at global and local scales by improving current fire history estimates and spatial distribution of burned areas. The effects of fire on biodiversity and soil degradation have been emphasized by several authors (Siegert et al. 2001, van Nieuwstadt et al. 2001), especially when the natural fire regimes are shortened. Fire regimes are a combination of many different aspects (fire frequency, size, length, seasonality, severity, and so on), and burned land products should be considered an important component of their analysis, including monitoring changes to the regimes and developing better understandings of the role of fire in current landscape spatial structure (Vega-Garcia and Chuvieco 2006). The AQL2004 project has shown a great potential to provide input data to undertake this ecological analysis.

\section{ACKNOWLEDGMENTS}

The AQL2004 project has been partially funded by the NASA-START program, which covered the costs for the technical meetings. Support from the GOFC-GOLD program is also acknowledged. The GLCF of the University of Maryland provided the MODIS 32-day composites and the active-fire data. High-resolution images for validation purposes were obtained from INPE, CONAE, and ERMEXS (Estación de recepción México de la Constelación SPOT). All participant institutions have provided support to the participants to share costs of processing the data and validating the results. Some of the Argentinean coauthors were financed from a grant of the Inter-American Institute for Global Change Research (IAI) CRN-203, which is supported by the U.S. National Science Foundation (Grant GEO-0452325). Elizabeth Hoy provided very useful comments and corrections.

\section{Literature Cited}

Ahern, F. J., J. G. Goldammer, and C. O. Justice. 2001. Global and regional vegetation fire monitoring from space: planning a coordinated international effort. SPB Academic Publishing, The Hague, The Netherlands.

Armenteras, D., M. Romero, and G. Galindo. 2005. Vegetation fire in the savannas of the Llanos Orientales of Colombia. World Resource Review 17:628-638.

Barbosa, P. M., J. M. Grégoire, and J. M. C. Pereira. 1999. An algorithm for extracting burned areas from time series of AVHRR GAC data applied at a continental scale. Remote Sensing of Environment 69:253-263.

Belward, A. S. 1996. The IGBP-DIS global $1 \mathrm{~km}$ land cover data set (DISCover)-proposal and implementation plans. IGBP-DIS Working Paper, Toulouse, France.

Boschetti, L., P. A. Brivio, H. D. Eva, J. Gallego, A. Baraldi, and J. M. Gregoire. 2006. A sampling method for the retrospective validation of Global Burned Area products. IEEE Transactions on Geoscience and Remote Sensing 44: 1765-1773.

Boschetti, L., H. D. Eva, P. A. Brivio, and J. M. Gregoire. 2004. Lessons to be learned from the comparison of three satellitederived biomass burning products. Geophysical Research Letters 31:L21501 [doi:21510.21029/22004GL021229].

Chuvieco, E., M. P. Martín, and A. Palacios. 2002. Assessment of different spectral indices in the red-near-infrared spectral domain for burned land discrimination. International Journal of Remote Sensing 23:5103-5110.
Cochrane, M. A., A. Alencar, M. D. Schulze, C. M. Souza, D. C. Nepstad, P. Lefebvre, and E. A. Davidson. 1999. Positive feedbacks in the fire dynamic of closed canopy tropical forests. Science 284:1832-1835.

Congalton, R. G., and K. Green. 1999. Assessing the accuracy of remotely sensed data: principles and applications. Lewis Publishers, Boca Raton, Florida, USA.

Di Bella, C. M., E. G. Jobbágy, J. M. Paruelo, and S. D. Pinnock. 2006. Continental fire density in South America. Global Ecology and Biogeography 15:192-199.

FAO. 2006. Global Forest Resources Assessment 2005. FAO, Rome, Italy.

Fernández, A., P. Illera, and J. L. Casanova. 1997. Automatic mapping of surfaces affected by forest fires in Spain using AVHRR NDVI composite image data. Remote Sensing of Environment 60:153-162.

Fraser, R. H., Z. Li, and J. Cihlar. 2000. Hotspot and NDVI Differencing Synergy (HANDS): a new technique for burned area mapping over boreal forest. Remote Sensing of Environment 74:362-376.

Giglio, L., J. Descloitres, C. O. Justice, and J. B. Kauffmam. 2003. An enhanced contextual fire detection algorithm for MODIS. Remote Sensing of Environment 87:273-282.

Giglio, L., G. R. van der Werf, J. T. Randerson, G. J. Collatz, and P. S. Kasibhatla. 2006. Global estimation of burned area using MODIS active fire observations. Atmospheric Chemistry and Physics 6:957-974.

Hansen, M. C., R. S. DeFries, J. R. G. Townshend, R. Sohlberg, C. Dimiceli, and M. Carroll. 2002. Towards an operational MODIS continuous field of percent tree cover algorithm: examples using AVHRR and MODIS data. Remote Sensing of Environment 83:303-319.

Hansen, M. C., J. R. G. Townshend, R. S. Defries, and M. Carroll. 2005. Estimation of tree cover using MODIS data at global, continental and regional/local scales. International Journal of Remote Sensing 26:4359-4380.

Justice, C. O., L. Giglio, S. Korontzi, J. Owens, J. T. Morisette, D. Roy, J. Descloitres, S. Alleaume, F. Petitcolin, and Y. Kaufman. 2002. The MODIS fire products. Remote Sensing of Environment 83:244-262.

Kasischke, E., and N. H. French. 1995. Locating and estimating the areal extent of wildfires in Alaskan boreal forest using multiple-season AVHRR NDVI composite data. Remote Sensing of Environment 51:263-275.

Key, C., and N. Benson. 2006. Landscape assessment (LA). Sampling and analysis methods. Pages LA1-LA51 in D. C. Lutes, R. E. Kenane, J. F. Caratti, C. H. Key, N. C. Benson, S. Sutherland, and L. J. Gangi, editors. FIREMON: fire effects monitoring and inventory system. Integration of standardized field data collection techniques and sampling design with remote sensing to assess fire effects. U.S. Forest Service, Rocky Mountain Research Station, Fort Collins, Colorado, USA.

Levine, J. S. 1996. Biomass burning and global change. MIT Press, Cambridge, Massachusetts, USA.

Liousse, C., M. O. Andreae, P. Artaxo, P. Barbosa, H. Cachier, J. M. Grégoire, P. Hobbs, D. Lavoué, F. Mouillot, J. Penner, M. Scholes, and M. G. Schultz. 2004. Deriving global quantitative estimates for spatial and temporal distributions of biomass burning emissions. Pages 77-120 in C. Granier, P. Artaxo, and C. E. Reeves, editors. Emissions of atmospheric trace compounds. Kluwer Academic Publishers, Dordrecht, The Netherlands.

López García, M. J., and V. Caselles. 1991. Mapping burns and natural reforestation using Thematic Mapper data. Geocarto International 1:31-37.

Martín, M. P. 1998. Cartografía e inventario de incendios forestales en la Península Ibérica a partir de imágenes NOAA-AVHRR. Dissertation. Universidad de Alcalá, Alcalá de Henares, Spain. 
Martín, M. P., P. Ceccato, S. Flasse, and I. Downey. 1999. Fire detection and fire growth monitoring using satellite data. Pages 101-122 in E. Chuvieco, editor. Remote sensing of large wildfires in the European Mediterranean Basin. Springer-Verlag, Berlin, Germany.

Martín, M. P., and E. Chuvieco. 1995. Mapping and evaluation of burned land from multitemporal analysis of AVHRR NDVI images. EARSeL Advances in Remote Sensing 4:7-13.

Martín, M. P., I. Gómez, and E. Chuvieco. 2005. Performance of a burned-area index (BAIM) for mapping Mediterranean burned scars from MODIS data. Pages 193-198 in J. Riva, F. Pérez-Cabello, and E. Chuvieco, editors. Proceedings of the Fifth International Workshop on Remote Sensing and GIS applications to Forest Fire Management: Fire Effects Assessment. Universidad de Zaragoza, GOFC-GOLD, EARSeL, Paris, France.

Morisette, J. T., J. L. Privette, and C. O. Justice. 2002. A framework for the validation of MODIS Land products. Remote Sensing of Environment 83:77-96.

Pereira, J. M. C. 1999. A comparative evaluation of NOAA/AVHRR vegetation indexes for burned surface detection and mapping. IEEE Transactions on Geoscience and Remote Sensing 37:217-226.

Roberts, S. J. 2000. Tropical fire ecology. Progress in Physical Geography 24:281-288

Roy, D., et al. 2005a. The Southern Africa Fire Network (SAFNet) regional burned area product validation protocol. International Journal of Remote Sensing 26:4265-4292.

Roy, D., Y. Jin, P. Lewis, and C. Justice. 2005b. Prototyping a global algorithm for systematic fire-affected area mapping using MODIS time series data. Remote Sensing of Environment 97:137-162.

Siegert, F., G. Rücker, A. Hinrichs, and A. Hoffmann. 2001. Increased damage from fires in logged forests during droughts caused by El Niño. Nature 414:437-440.
Simon, M., S. Plummer, F. Fierens, J. J. Hoelzemann, and O. Arino. 2004. Burnt area detection at global scale using ATSR-2: the GLOBSCAR products and their qualification. Journal of Geophysical Research-Atmospheres 109:D14S02 [doi:10.1029/2002JD003622:1-16].

Tansey, K., et al. 2004. Vegetation burning in the year 2000: global burned area estimates from SPOT VEGETATION data. Journal of Geophysical Research-Atmospheres 109: D14S03 [doi:10.1029/2002JD003598:2-22].

Townshend, J. R., R. DeFries, M. Hansen, R. Sohlberg, M. Carroll, and C. DiMiceli. 2003. MODIS 32-day composites. The Global Land Cover Facility, College Park, Maryland, USA.

Trigg, S., and S. Flasse. 2000. Characterizing the spectraltemporal response of burned savannah using in situ spectroradiometry and infrared thermometry. International Journal of Remote Sensing 21:3161-3168.

van der Werf, G. R., J. Randerson, T. G. J. Collatz, L. Giglio, P. S. Kasibhatla, A. F. Arellano, S. C. Olsen, and E. S. Kasischke. 2004. Continental scale-partitioning of fire emissions during the 1997 to $2001 \mathrm{El}$ Niño/La Niña period. Science 303:73-76.

van der Werf, G. R., J. T. Randerson, L. Giglio, G. J. Collatz, P. S. Kasibhatla, and A. F. Arellano. 2006. Interannual variability in global biomass burning emissions from 1997 to 2004. Atmospheric Chemistry and Physics 6:3423-3441.

van Nieuwstadt, M. G. L., D. Sheil, and K. Kartawinata. 2001. The ecological consequences of logging in the burnt forests of East Kalimantan, Indonesia. Conservation Biology 15:11831186.

Vega-Garcia, C., and E. Chuvieco. 2006. Applying local measures of spatial heterogeneity to Landsat-TM images for predicting wildfire occurrence in Mediterranean landscapes. Landscape Ecology 21:595-605. 